\title{
オリゴソープの部分モル容積による分類と その界面活性との相関
}

\author{
石上裕 \\ 工業技術院東京工業試験所（東京都啮谷区本町 1-1-5）
}

\begin{abstract}
Classification of Oligosoaps by Partial Molal Volume and the Correlation with Surface Activity in Aqueous Solution
\end{abstract}

Yutaka IsHIG AMI

National Chemical Laboratory for Industry

(1-chome, Hon-machi, Shibuya-ku, Tokyo)

\begin{abstract}
Surface active properties of anionic oligosoap homologues prepared from alternating cooligomers of maleic acid derivatives and alkyl vinyl ethers having $\mathrm{C}_{2} \sim \mathrm{C}_{16}$ alkyl groups were measured and classified by the differences of their partial molal volumes in aqueous solutions, that is, the ratios $(R)$ of the observed partial base molal volumes $\left(\phi_{v}{ }^{0}\right)$ to the calculated ones (the summation of atomic volume) were introduced as an index for the classification, and this idea was applicable especially to the oligosoaps having $\mathrm{C}_{10} \sim \mathrm{C}_{16}$ side chain while the corresponding $\mathrm{C}_{2}$ and $\mathrm{C}_{4}$ derivatives were not fitted owing to their polyelectrolyte behaviors.

It was ascertained that solubilizing and emulsifying powers of aqueous oligosoap solutions were colligatively estimated by $\mathrm{R}$ values, independently on their chemical structures. Furthermore, it was found that there was a minimum in the plot of surface tention vs. alkyl side chain length of oligosoaps, and such phenomenon was attributed to the inhibition of surface adsorption of originally bulky and immobile oligosoap molecules in aqueous solution owing to the strong trend of their intermolecular aggregation. Namely, $\mathrm{C}_{16}$ derivative seems to give a high surface tension $(68 \mathrm{dyn} / \mathrm{cm}$ ) near that of water in aqueous solutions, as the result that their surface adsorptions at the air-solution interface competed with their own intermolecular aggregations. Furthermore, wetting, dispersing, and flocculating behaviors of oligosoaps were also examined.
\end{abstract}

\section{1 緒 言}

通常の界面活性剂(モノソープ)水溶液の示す界面活性 は，化学構造にかかわらず HLB 価などによって一義的 に決められるが，オリゴソープなどの高分子性界面活性 物質に関してこのような概念は従来考えられていない。 前報 ${ }^{1)}$ において, 著者らはアニオン性の高分子性界面活 性物質の化学構造と部分モル容積 $\left(\phi_{v}{ }^{0}\right)$ との関係を明ら かにした。 $\phi_{v}{ }^{0}$ の大きさの変化は, 主にイオンによる電 縮効果と疎水基による水構造形成効果に依存するが，さ らに分子会合などに基づく分子内の不整とん(頓)にもか かわりがあり，上記物質の水溶液の界面活性に関連する 特性值として使用できる可能性が考えられた。しかし， $\phi_{v}{ }^{0}$ の大きさは分子量によって大きく変わるのでそのま までは利用しにくい。そこで, 本報では原子容の和とし
ての $\phi_{v}{ }^{0}$ を計算し，これに対する実測の $\phi_{v}{ }^{0}$ の比 $(\mathrm{R})$ と いう概念を導入し，界面活性効果の予測ができるかどう か研究した。すなわち,オリゴソープなどの高分子性界 面活性物質の化学構造の一部を系統的に変化させた時, 束一的な R の值の変化济伴って各種の界面活性 (可溶化 力, 乳化力, 分散力, 凝集力, 表面張力低下能, 浸透力) が一定の規則性を保ちながら変化する状況を研究した。

\section{2 実験}

\section{$2 \cdot 1$ 試 料}

$2 \cdot 1 \cdot 1$ 試 薬

エチルベンゼンは，市販試薬特級品を Nester-Faust 回転バンド式精留カラム NF-275 (理論段数 45 段) を用 いて精留し，136.2 136.4 ${ }^{\circ} \mathrm{C}$ の留分を採取した。水は, 前報1) と同様の再蒸留水を使用した。カーボンブラック 
(日産化学 G 3 粉末) 及び二酸化マンガン（市販試薬特 級品）は 100 200 mesh の部分をふるい分け, $30^{\circ} \mathrm{C} に$ て相対湿度 $60 \%$ に保ったデシケーター中に保存した。 カオリンは Fisher 科学 (株) 製 K-5 グレード (酸洗) をふるい分け, 200 300 mesh の部分を $30^{\circ} \mathrm{C}$ にて相対 湿度 $60 \%$ で保存した後測定に供した。硫酸ドデシルナ トリウムは Eastman 社製試薬を用いた。エーロゾルOT [1,2-ビス（2-エチルヘキシルオキシカルボニル)-1-エ タンスルホン酸ナトリウムは，市販品よりアセトン及 び石油エーテル不溶分を除いて使用した。デモールNは 花王石畭 (株) 製でナフタレンスルホン酸ナトリウムホ ルマリン縮合物である。ポリアクリルアミドは, 和光純 薬 (株) 製で重合度 1 万のものを使用した。また, 三洋 化成 (株) 製凝集剂サンフロック $\mathrm{AH}-150 \mathrm{P}, \mathrm{N}-50 \mathrm{P}$ 及 び C-450を使用した。

$2 \cdot 1 \cdot 2$ オリゴソープなど

前報 ${ }^{1)}$ と同じものを用いた。無水マレイン酸とアルキ ルビニルエーテルとの交互共重合体けん化物（以下M系 列という) 及びマレイン酸ジエルチルとアルキルビニル エーテルとの交互共重合体けん化物（D系列という）で あって, 側鎖のアルキルエーテル鎖長, 対イオン $(\mathrm{K}$ ま たは $\mathrm{Na}$ ，けん化度及び繰り返し単位数の異なる多数の 誘導体を合成した。試料名は略号で示した。例えば, $\mathrm{C}_{2} \mathrm{D}-\mathrm{K} 89$ は， D系列でアルキルエーテル基がエチル基， 対イオンが $\mathrm{K}$, マレイン酸基のけん化度が $89 \%$ である ことを意味する。なお, 数平均の繰り返し単位数 $(n)$ は 下記の通りである。

\begin{tabular}{lr|ll}
\hline $\mathrm{C}_{2} \mathrm{M}$ & 24 & $\mathrm{C}_{2} \mathrm{D}$ & 3 \\
$\mathrm{C}_{4} \mathrm{M}$ & 72 & $\mathrm{C}_{4} \mathrm{D}$ & 4 \\
$\mathrm{C}_{10} \mathrm{M}$ & 93 & $\mathrm{C}_{10} \mathrm{D}$ & 7 \\
$\mathrm{C}_{12} \mathrm{M}$ & 22 & $\mathrm{C}_{12} \mathrm{D}$ & 6 \\
$\mathrm{C}_{16} \mathrm{MA}$ & 12 & & \\
$\mathrm{C}_{16} \mathrm{MB}$ & 55 & & \\
$\mathrm{C}_{16} \mathrm{MC}$ & ca 530 & & \\
\hline
\end{tabular}

\section{2 実験方法}

$2 \cdot 2 \cdot 1$ 密 度

オーストリア Anton Paar 社デジタル精密密度計 DMA-10 型を用い, $30 \pm 0.01^{\circ} \mathrm{C}$ にて測定した。溶液密 度の側定值から繰り返し単位当たりの見掛けのモル容積 $\left(\phi_{v}\right)$ 及び部分モル容積 $\left(\phi_{v}{ }^{0}\right)$ を計算した。詳細は前 報1に述べた。

\section{$2 \cdot 2 \cdot 2$ 可溶化力}

ガラス製アンプルに所定量のエチルベンゼン及び 0.1 , $0.05,0.01$ base $\mathrm{mol} / l$ のオリゴソープ水溶液を加えて溶 封し, $45^{\circ} \mathrm{C}$ にて $6 \mathrm{~h}$ 振りまぜた後 $30 \pm 0.01^{\circ} \mathrm{C}$ にて $4 \mathrm{~d}$ 振りまぜた。肉眼により油滴の浮遊の有無を観察して溶 液のエチルベンゼンに対する飽和可溶化量を決定した。

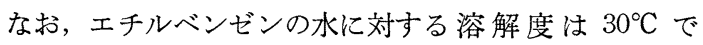

$0.02010 \mathrm{ml} / \mathrm{dl}$ 水なので, この值を差し引いて溶液の可 溶化力を計算した。

\section{$2 \cdot 2 \cdot 3$ 乳化力}

$30 \mathrm{ml}$ の目盛付試験管にオリゴソープ水溶液 $3 \mathrm{ml}$ と エチルベンゼン $2 \mathrm{ml}$ を加え, $95^{\circ} \mathrm{C}$ の水中に入れ同温度 にする。これを振とう機で振りまぜた $(30 \mathrm{~s}$ に振幅 $25 \mathrm{~cm}$ で 120 回垂直に振とう) 後直ちに $95^{\circ} \mathrm{C}$ の恒温水そう 中に入れ, 時間（振とう $5 \mathrm{~min}$ 後より $120 \mathrm{~min}$ 後まで） とともに分離油層, 乳化層, 分離水層を読み取り, 下図 のように作図する。斜線の部分が乳化層であり，振とう

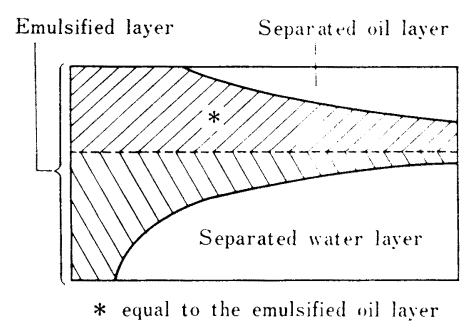

前に油一水層の高さを読み取っておき, 図中の点線のよ うに乳化層を横軸に平行に切れば，乳化層中の点線より 上の部分は用いた油の中の乳化された油の量に当たるの で油層中の乳化油層の面積の百分㴶を求め, これを乳化 率 $(\%)$ として算出した。

$2 \cdot 2 \cdot 4$ 表面張力

$\mathrm{du}$ Nöuy の表面張力計を用い, $30 \pm 1^{\circ} \mathrm{C}$ で測定した。 測定容器に入れて $20 \mathrm{~min}$ 後に測定した。ほぼテ衡値で あった。

\section{$2 \cdot 2 \cdot 5$ 浸透力}

厚さ $0.2 \mathrm{~cm}, 2 \mathrm{~cm} \times 2 \mathrm{~cm}$ の正方形のフェルト, $2 \mathrm{~cm}$ $\times 2 \mathrm{~cm}$ の大和紡，帆布 \#6 号を試験片として用い，30 $\pm 1^{\circ} \mathrm{C}$ にて自然沈降法により測定した。すなわち, ピン セットで試験布の両端を軽くはさみ, 水面 $5 \mathrm{~mm}$ 上から 静かに離して落とす。溶液面に布がふれた瞬間からスト ップウォッチを押して計時し, 布が液面から完全に離れ た瞬間までの秒数を読んだ。最高 $500 \mathrm{~s}$ まで測定した。 $2 \cdot 2 \cdot 6$ 分散力

カーボンブラックまたは二酸化マンガン $50 \mathrm{mg}$ を 30 $\mathrm{ml}$ の目盛付試験管に取り, 試料溶液 $20 \mathrm{ml}$ を加え $30^{\circ} \mathrm{C}$ とし, 振とう機で垂值に振りまぜ (30s 120 回, 振幅 25 $\mathrm{cm}), 30^{\circ} \mathrm{C}$ にて $4 \mathrm{~h}$ 静置する。ついで, 試験管の液面か ら $5 \mathrm{ml}$ の目盛線までピペットの先端を入れ, その部分 から $2 \mathrm{ml}$ を吸いとり, 別の試験管に移す。これに水を $25 \mathrm{ml}$ 加えた液 (A) につき, 光電比色計（日立パーキ ンエルマー 139 UV-VIS 光電光度計, $445 \mathrm{~nm}$ のフィル ターを使用）を用いて測定し, 次式に従って分散力を求 めた。

$$
\text { 分散力 }=\frac{T_{0}-T_{s}}{T_{0}} \times 100
$$


ここで, $T_{0}$ : 被検溶液 $2 \mathrm{ml}$ に水 $25 \mathrm{ml}$ を加えた水溶液 の透過率, $T_{s}:$ 上記 $(\mathrm{A})$ の透過率。

$2 \cdot 2 \cdot 7$ カオリン照濁液化対する凝集力

沈降速度測定：カオリン $1.25 \mathrm{~g}$ を内径 $1.5 \mathrm{~cm}$, 高さ $21 \mathrm{~cm}$ の $30 \mathrm{ml}$ 容共せん目盛付試験管に入れ, 水を加えて $23.5 \mathrm{ml}$ とし, よく振りまぜる。数分後, 試料の $0.01 \%$ 水溶液 $1.5 \mathrm{ml}$ 添加して $25 \mathrm{ml}$ とし, $30 \mathrm{~s}$ に 10 回転 倒してかきまぜた。かきまぜた後直ちに試験管を垂直に 立て, 沈降界面の目盛を所定時間ごとに読んで, 初期の $25 \mathrm{ml}$ から $15 \mathrm{ml}$ 实での等速沈降部分在以て沈降速度と した。沈降速度は $\mathrm{ml} / \mathrm{min}$ で示した。

清澄性: 沈降速度を測定しながら, 清澄性を定性的に 肉眼観察によって表現した。沈降界面が約半分になった ところで, 上澄み液の清澄性を，○良い， 少し濁って いる，×濁っている上いう三段階に分けた。定量的には 沈降試験開始 $5 \mathrm{~min}$ 後の上澄み液の $600 \mathrm{~nm}$ における 透過率で表した。

最終沈降容積：24h ほど経過すると沈降界面はほぼ 平衡值に到達するので, その時の沈降容積を最終沈降容 積 $\left(v_{f}\right)$ と呼び, $\mathrm{ml}$ で示した。

沪過速度測定：下図のようなブフナー漏斗（底の直径 $3 \mathrm{~cm}$ ）に東洋沪紙 No. $5 \mathrm{C}$ の沪紙を敷いて,アスピレー ターで大気压加ら $15 \pm 1 \mathrm{mmHg}$ だけ減圧にして吸引沪 過を行った。すなわち, v $v_{f}$ 测定後の凝集しているカオ リンを静かに 10 问ほど転倒してかきまぜ，均一にほぐ した矁濁液をブフナー漏斗上へすばやく注ぎこみ沪過し た。流出する沪液をメスシリンダーに受け, 所定時間ご とに沪液量を読んで, 沪過液量対時間プロットの等速部 分をとって沪過速度上し， $\mathrm{ml} / \mathrm{min}$ で示した。

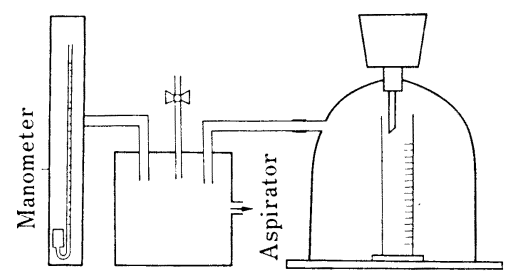

\section{3 実験結果及び考察}

\section{1 繰り返し単位についての部分基本モル容積 $\left(\boldsymbol{\phi}_{v}{ }^{0}\right)$ の実測值と計算值との関係}

モノソープの部分モル容積は, 構成原子の原子容の和 として求めることができる。そして, Traube の方法に 従って計算した部分モル容積は, 臨界ミ七ル濃度 $(\mathrm{cmc})$ 以下の濃度における水溶液の部分モル容積の実測 值とよく一致し, cmc 以上のミセル形成領域の場合は, 上記の計算値に, これと液状炭化水素とのモル容積差分 (covolume) を加えると実測值とよく一致した ${ }^{2)}$ 。

完全けん化したオリゴソープの繰り返し単位（基本分
子モル）当たりの $\phi_{v}{ }^{0}$ を計算し, 前報1の Fig.-7 と8 における実測の $\phi_{v}{ }^{0}$ 対けん化度プロットを外そうして完 全けん化物の $\phi_{v}{ }^{0}$ を求めると両者は比較的近い值であっ た。Fig.-1 及び 2 に $\phi_{v}^{0}$ の実測值と計算值との関係を 示した。Fig.-1 に扔いて, M系列の $\mathrm{C}_{10}, \mathrm{C}_{12}$ 及び $\mathrm{C}_{16}$ のK塩及び $\mathrm{Na}$ 塩の完全けん化物の実測值は計算值より わずかに小さい。 $50 \%$ けん化物の実測值は計算値よりも さらに小さいので, けん化度の低下とともに分子が全体 として収縮する傾向のあることがわかる。けん化度が同 じならばK塩と Na 塩とはほぼ同じ值である。そして,

$\mathrm{K}$ 塩では $\mathrm{C}_{4}$ 付近で等量プロットから急速に下方へずれ， $\mathrm{C}_{2}$ ではかなり低い值を示す。 $\mathrm{Na}$ 塩では落ちこみが小さ いが同様の傾向である。この理由として，短鎖アルキル

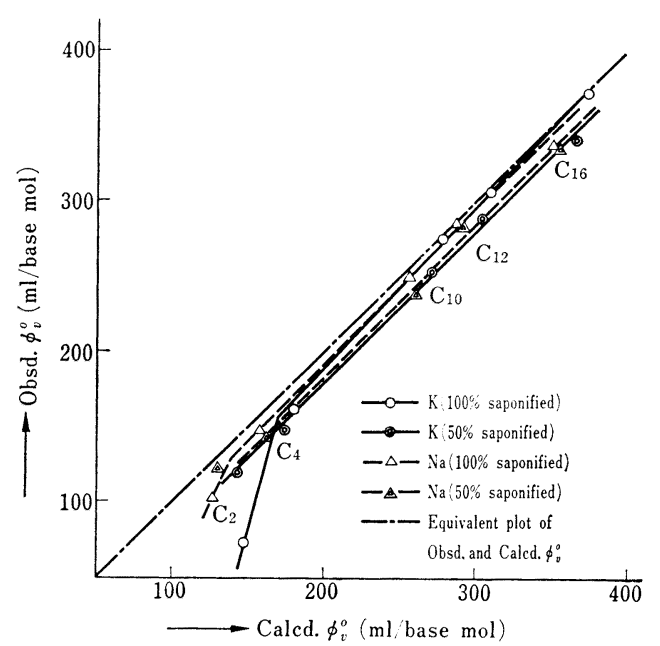

Fig.-1 Relationships between observed and calculated partial base molal volumes $\left(\phi_{v}{ }^{0}\right)$ of M-series derivatives in aqueous solution at $30^{\circ} \mathrm{C}$.

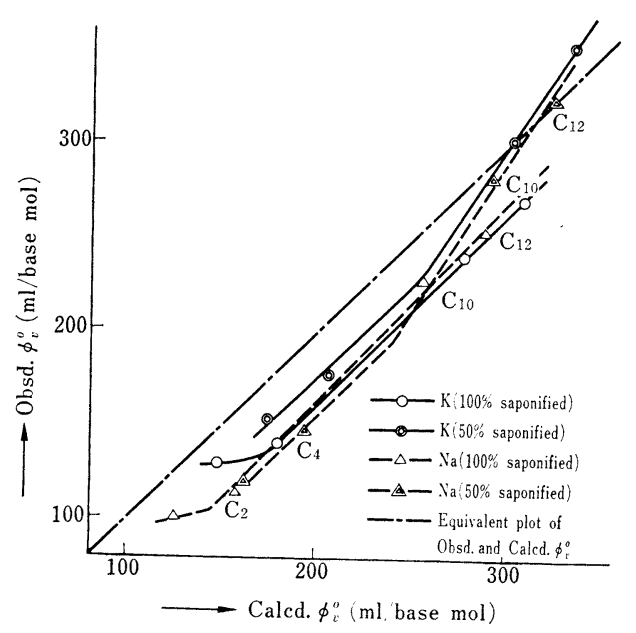

Fig.-2 Relationships between observed and calculated partial base molal volumes $\left(\phi_{v}{ }^{0}\right)$ of D-series derivatives in aqueous solution at $30^{\circ} \mathrm{C}$. 
基の場合，オリゴマーイオン基の効果とオリゴマー踈水 基とのバランスが崩れ，オリゴマーイオンによる電縮効 果が優位に立つためと思われる。すなわち, 高分子電解 質からオリゴソープヘの遷移が $\mathrm{C}_{2} \sim \mathrm{C}_{4}$ の間で起こるこ とを意味する。さらに，50\%けん化物については， $\mathrm{C}_{2}$ 及び $\mathrm{C}_{4}$ も，また $\mathrm{C}_{10}, \mathrm{C}_{12}, \mathrm{C}_{16}$ のプロットとほぼ同一 線上に乗るので，イオン基と疎水基とのバランスが保た れたままであることがわかる。また，分子中のアルキル 基含量に対応して側鎖アルキル基が $\mathrm{C}_{10}$ 以上の長いもの ほど完全けん化物の $\phi_{v}{ }^{0}$ の実測值が計算值に近づく傾向 があるが，側鎖アルキル基の集合体（分子内または分子 間会合体 $)^{3), 4)}$ の数と個々の大きさに対応している可能 性が考えられる。しかし, モノソープとちがって実測值 が計算值を越えないので疎水領域の内部が液状炭化水素 と見なせるほど集合体の大きさ（構成アルキル基数）が 大きくならないものと思われる。

他方, 全体として見ると，D系列は，M系列に比べて さらに実測值の方が計算值よりも小さくなっている (Fig. - 2)。これは柾水基の枝分孔効果 ${ }^{5}$ による $\phi_{v}{ }^{0}$ の減 少のためであろう。すなわち，D系列は繰り返し単位に ついてアルキルエーテル基とマレイン酸エチル基とを持 つが，M系列は前者だけである。 $\mathrm{C}_{10}$ 及び $\mathrm{C}_{12}$ の長鎖ア ルキル唀導体の $50 \%$ けん化物の場合， $\phi_{v}{ }^{0}$ の実測值が 計算值と同等またはこれよりも大きくなるので，より 大きな疎水領域の形成が考えられる。すなわち，D系列 の $50 \%$ けん化物においては，分子内の疎水部がコンパ クトにパッキングすることによって，大きな分子間会合 体を形成する ${ }^{3,4}$, 4) ため，実測の $\phi_{v}{ }^{0}$ が大きくなるものと して説明できる。

\section{$3.2 \phi_{v}{ }^{0}$ の計算値に対する実測值の比 $(\mathbf{R})$ を用いる オリゴソープの分類}

Fig.-1 及び 2, さらに前報りに打ける $\phi_{v}{ }^{0}$ がオリゴ ソープの側鎖アルキル基鎖長またはけん化度に依存する 状況から, 水溶液中におけるオリゴソープの $\phi_{v}{ }^{0}$ とその 界面活性効果とが相関することが推定された。このよう な相関関係があれば，それは束一的であって化学構造に 無関係に成り立つのでオリゴソープの界面活性の評価分 類法として使用できることが期待される。同一の尺度で 表す方法の一つとして $\phi_{v}{ }^{0}$ の計算值に対する実測值の 比 $(\mathrm{R})$ をとると，側鎖アルキル基の小さいものほど $\mathrm{R}$ が小さいことがわかった。さらに，文献よりポリアクリ ル酸ナトリウム $(\mathrm{NaPA})^{6)}$ とポリメタクリル酸カリウム $(\mathrm{KPMA})^{7)}$ についてRを計算すると，本研究における $\mathrm{C}_{2}$ 及び $\mathrm{C}_{4}$ の短鎖誘導体と同様に $0.6 \sim 0.9$ であった。 従って, 高分子電解質の示す $\mathrm{R}$ 值はオリゴソープのそれ よりも小さいといら結論を得た。これは，オリゴソープ のような両媒分子の $\phi_{v}{ }^{0}$ が主として極性基による電縮 効果と疎水基による水構造形成効果に二大別できること
を示すのであろう。しかし， $\mathrm{C}_{2} \mathrm{M}-\mathrm{K}$ 及び $\mathrm{C}_{2} \mathrm{D}-\mathrm{K}$ 誘導 体のように必ずしもRが小さくない例もある（Fig.-3 及び 4 におうる横軸の $\mathrm{R}$ の大きを比較)。これは, 前 記の二つの効果のバランスに加えて void space の効 果 ${ }^{8)}$ 及び分子会合による疎水性の増大 ${ }^{2)}$ の効果などがあ るためであろう。

このようにして， $\mathrm{R} の$ 絶対值の比較だけでは分類法と して不充分なことがわかったので, 二次元的な尺度で分 類するための単なる便法としてオリゴソープの繰り返し 単位について Davies の HLB 価を求め, $\mathrm{R}$ との関係を Fig.-3 及び 4 に示した。Fig.-3 亿見るように，M系列 の HLB 価対Rプロットは扇形をなし, 高分子電解質で ある $\mathrm{C}_{2} \mathrm{M}$ 誘導体は最左端にあって負こう配である ( $\mathrm{NaPA}$ 及び KPMA も同じ) が, $\mathrm{C}_{4} \mathrm{M}, \mathrm{C}_{10} \mathrm{M}, \mathrm{C}_{16} \mathrm{M}$ と 徐々に右側（Rが大きい側）に移行するとともに正こう

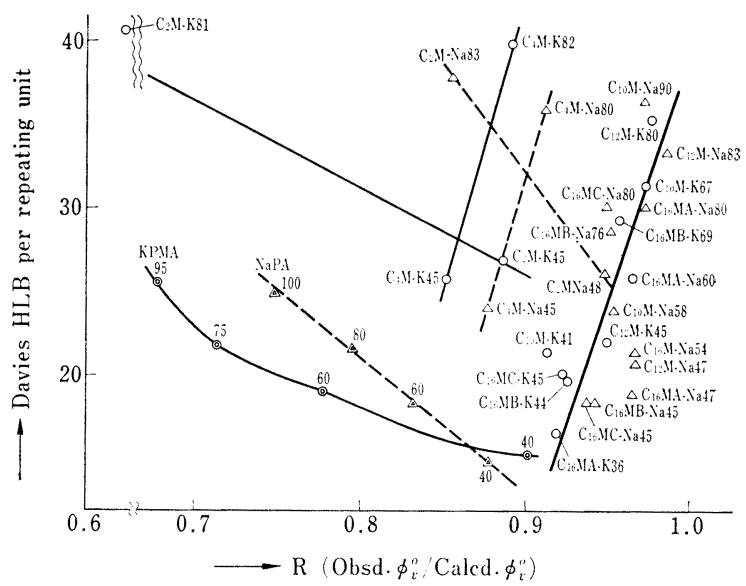

Fig.-3 Classification of $\mathrm{M}$-series oligosoaps in relation to surface activity by the ratio( $R)$ of observed $\phi_{v}{ }^{0}$ to calculated one, and subsidiarily calculated HLB per repeating unit.

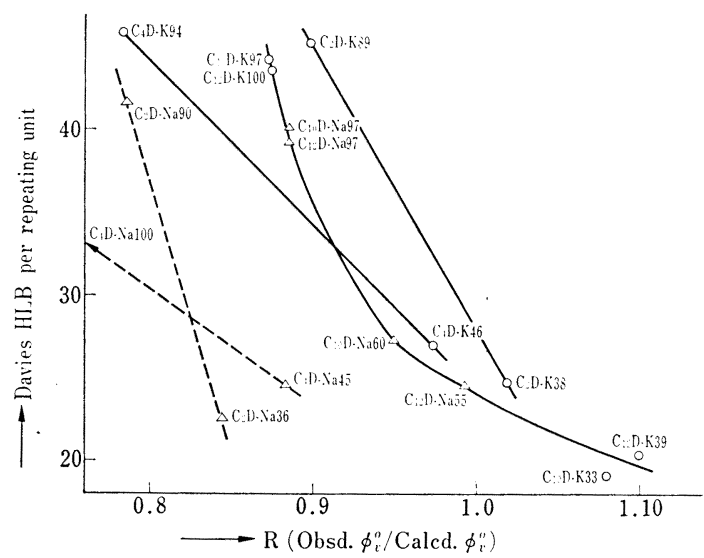

Fig.-4 Classification of $D$-series oligosoaps in relation to surface activity by the ratio $(R)$ of observed $\phi_{v}{ }^{0}$ to calculated one, and subsidiarily calculated HLB per repeating unit. 
配になる。特に, $\mathrm{C}_{10} \sim \mathrm{C}_{16}$ の間では化学構造によらず束 一的な直線関倸がある。この中で, 低けん化度のものは Rが小さく, HLB 価が小さいのに対して, 高けん化度 のものはRが大きく, HLB 価が大きい。Fig. -4 は D系 列の場合である。 $\mathrm{M}$ 系列のプロットとちがい， $\mathrm{C}_{10}$ 以上 であっても負こう配であるが，正確に同一線上に乗って いる。

\section{3 可溶化力と $\mathbf{R}$ との関係}

高分子電解質水溶液は油を可溶化できないが，高分子 電解質に対して何らかの方法で化学結合されたアルキル 基を導入してやると, その水溶液が可溶化力を現すよう になることはすでによく知られている。モノソープが示 す界面活性は, ミセル形成能に起因する界面活性と表面 張力低下能に起因するそれとに分けられる が, 前者に よって可溶化力がもたらされる。オリゴソープなどの高 分子性界面活性物質も, 水溶液中において疎水領域 (分 子内ミセル及び分子間会合体などの側鎖アルキル基の集 合した可溶化少イト）を形成することによって可溶化現 象を示すのである。これらの水溶液のエチルベンゼンに 対する飽和可溶化量を測定した。エチルベンゼンは, オ リゴソープの疎水領域の中心に可溶化されるのでオリゴ ソープの疎水領域の大きさを知るのに適すると考えてこ れを選んだ。

Fig.-5 は $\mathrm{C}_{10} \sim \mathrm{C}_{16}$ の系列について, 濃度が 0.1, 0.05 及び 0.01 base $\mathrm{mol} / \mathrm{l}$ の時の可溶化力対 $\mathrm{R}$ の関係 である。側鎖アルキル基鎖長, 対イオン及びけん化度に

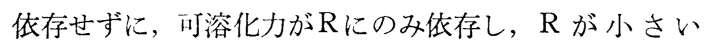
ほど可溶化力が大きいという関係がある。 0.05 base $\mathrm{mol} / l$ の場合の測定点だけを図示し, 0.1 及び 0.01 base $\mathrm{mol} / l$ の場合は測定点を省いて関倸曲線だけを示した。 測定点がかなりばらついているが，両者の間には確ふに 相関関倸がある。Fig.-6 は， $\mathrm{C}_{10}$ 及び $\mathrm{C}_{12}$ のD系列につ いての可溶化力対 $\mathrm{R}$ の関係である。 $\mathrm{D}$ 系列の場合には非 常に正確に両者が相関していることがわかる。そして,

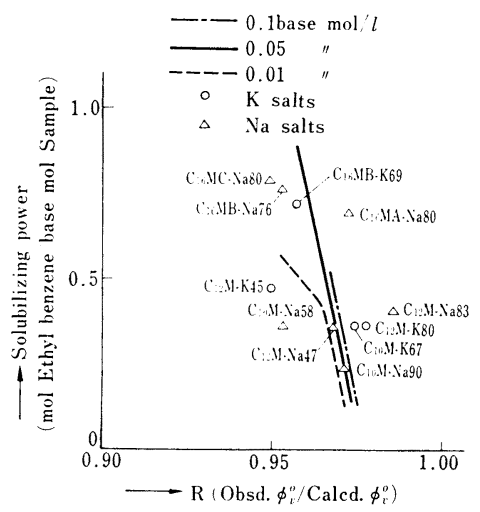

Fig.-5 Solubilizing power $v s$. $\mathrm{R}$ plots of $\mathrm{M}$-series oligosoaps.

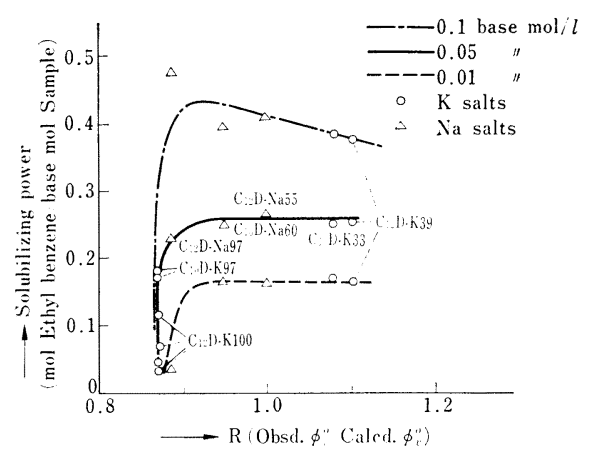

Fig.-6 Solubilizing power vs. $\mathrm{R}$ plots of $\mathrm{D}$-series oligosoaps.

Rが小さい時可溶化力が小さいが， Rを増すとともに可 溶化力は急増し, $\mathrm{R}=0.92$ でほぼ一定值に到達する。

$\mathrm{M}$ 系列と $\mathrm{D}$ 系列の可溶化挙動を比較すると，(1) 前者 はRが小さい方が可溶化力が大きく，後者はRが大きい ほど可溶化力が大きい。また，(2) 可溶化力の絶対值は M系列の方がはるかに大きい。両者の相違として，(a) 同一分子中に化学結合された繰り返し単位数 $(n)$ の相違

(M系列は数十以上, D系列は十以下")) と (b) 化学構 造の相違（側鎖疎水基としてM系列はアルキルエーテル 基のみ， D系列はこれに加えてマレイン酸エチル基を持 つ）とが考えられるが，(1) は主として（b)，(2) は主 として (a) によってひき起こされるものと考えられる。 すなわち, ポリソープの場合, 収縮した構造 (Rが小さ い) は, 水液中における疎水領域の存在を意味し10), 可 溶化力などに優れることが知られている。従って，M系 列の場合のようにRが小さいほど可溶化力が大きいとい ら挙動が公知の挙動であって, 側鎖アルキル基鎖長及び 主鎖アルキル基鎖長（重合度）が大きいものほど可溶化 力が大きいといい換えることができる。これに対して， D系列のようにRが大きいほど可溶化力が大きいという 挙動は従来明らかにされておらず, 可溶化サイト（疎水 領域）のかさ高さ（void space の存在）もまたエチルベ ンゼンの问溶化に必要な要素であることが明らかになっ

Table-1 Solubilizing power of aqueous solutions of $\mathrm{C}_{2}$ and $\mathrm{C}_{4}$ derivatives at the concentration of 0.1 base $\mathrm{mol} / \mathrm{l}$ at $30^{\circ} \mathrm{C}$.

\begin{tabular}{c|c}
\hline & $\begin{array}{l}\text { Solubilizing power } \\
\text { (mol Ethyl benzene/base mol Sample) }\end{array}$ \\
\hline $\mathrm{C}_{2} \mathrm{M}-\mathrm{K} 81$ & 0.003 \\
$-\mathrm{Na} \mathrm{83}$ & $\prime \prime$ \\
$\mathrm{C}_{4} \mathrm{M}-\mathrm{K} 82$ & 0.024 \\
$-\mathrm{Na} \mathrm{80}$ & $\prime \prime$ \\
$\mathrm{C}_{2} \mathrm{D}-\mathrm{Na} 90$ & 0 \\
$-\mathrm{Na} \mathrm{36}$ & 0 \\
$\mathrm{C}_{4} \mathrm{D}-\mathrm{K} 94$ & 0.024 \\
$-\mathrm{K} 46$ & 0.023 \\
$\mathrm{SD} \mathrm{S}$ & 0.326 \\
\hline
\end{tabular}


た。この場合, 可溶化力は小さい值で飽和してしまうよ らである。

Table-1 は $\mathrm{C}_{2}$ 及び $\mathrm{C}_{4}$ 誘導体のエチルベンゼンに対 する可溶化力である。Fig.-5 及び 6 における $\mathrm{C}_{10}$ 以上 のアルキル基を持つものに比べて著しく可溶化力が小さ い。さて, イオンの部分モル容積 $\phi_{v^{0}}{ }^{\text {, ion }}=\phi_{v^{0}}{ }$, cryst + $\phi_{v}{ }^{0}$,elect $+\phi_{v}{ }^{0}$,disord $+\phi_{v}{ }^{0}$,caged という要素に分けられる ${ }^{8)}$ 。ここで, $\phi_{v}{ }^{0}$, cryst $:$ 結晶の部分モル容積; $\phi_{v}{ }^{0}$, elect : 電縮効果による部分モル容積への寄与（イオン一溶媒相 互作用による容積の減少); $\phi_{v}{ }^{0}$, disord : 不整とんの度合 の部分モル容積への寄与(溶液中のイオンの周りの void

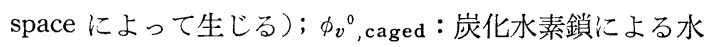
構造の形成の部分モル容積への寄与である。側鎖アルキ ル基が $\mathrm{C}_{4}$ 以下では，Fig.-1 及び 2 に見るように $\phi_{v^{0}}{ }^{\text {,elect }}$ が圧倒的に大きいので, 分子は伸長して可溶化 サイトが形成されにくく, それらの可溶化力注 $\mathrm{C}_{10}$ 以上 のものに比べて著しく劣るものと思われる。

\section{$3 \cdot 4$ 乳化力と $\mathbf{R}$ との関係}

Table-2 に, $\mathrm{M}$ 系列の全部と $\mathrm{D}$ 系列の中 $\mathrm{C}_{2}$ 及び $\mathrm{C}_{4}$ 誘導体のエチルベンゼンに対する乳化力を示した。M系 列の乳化力は $\mathrm{C}_{2}$ から $\mathrm{C}_{16}$ までいずれも乳化力が小さか った。すなわち， $\mathrm{C}_{10}$ 以上のアルキル基を持つむのは， それらの優れた可溶化力とは対照的に乳化力が劣ってい る。これは，モノソープにおける HLB 価と用途との関

Table-2 Emulsifying power of aqueous solutions of oligosoaps at the concentration of 0.05 base $\mathrm{mol} / l$.

\begin{tabular}{|c|c|}
\hline & $\begin{array}{l}\text { Emulsifying } \\
\text { rate }(\%)\end{array}$ \\
\hline $\mathrm{C}_{2} \mathrm{M}-\mathrm{K} 81$ & 17 \\
\hline$-\mathrm{Na} 83$ & 15 \\
\hline $\mathrm{C}_{1} \mathrm{M}-\mathrm{K} 82$ & 55 \\
\hline$-\mathrm{Na} 80$ & 9 \\
\hline $\mathrm{C}_{10} \mathrm{M}-\mathrm{K} 67$ & 22 \\
\hline$-\mathrm{Na} 90$ & 49 \\
\hline $\mathrm{C}_{12} \mathrm{M}-\mathrm{K} 80$ & 20 \\
\hline$-\mathrm{Na} 83$ & 7 \\
\hline $\mathrm{C}_{16} \mathrm{MA}-\mathrm{Na} 80$ & 59 \\
\hline B- K 69 & 4 \\
\hline B-Na 76 & 0 \\
\hline C-K 82 & 40 \\
\hline $\mathrm{C}-\mathrm{Na} 80$ & 14 \\
\hline $\mathrm{C}_{2} \mathrm{D}-\mathrm{K} 89$ & 31 \\
\hline$-\mathrm{K} 38$ & 88 \\
\hline$-\mathrm{Na} 90$ & 52 \\
\hline$-\mathrm{Na} 36$ & 77 \\
\hline $\mathrm{C}_{4} \mathrm{D}-\mathrm{K} 94$ & 100 \\
\hline$-\mathrm{K} 46$ & 100 \\
\hline$-\mathrm{Na} 100$ & 89 \\
\hline$-\mathrm{Na} 45$ & 75 \\
\hline S D S & 100 \\
\hline
\end{tabular}

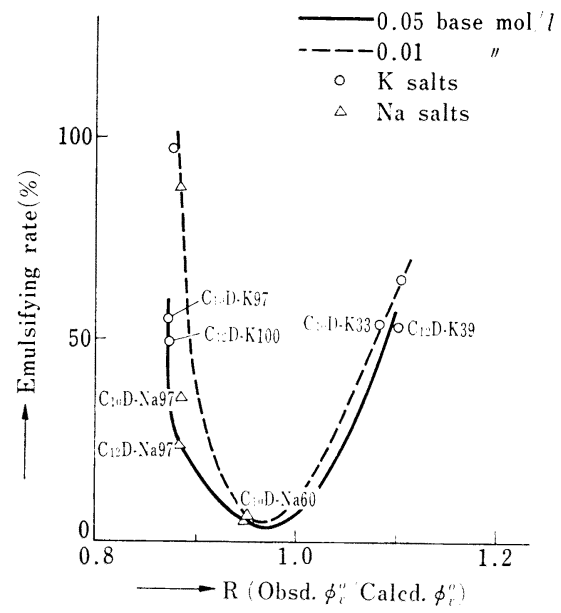

Fig.-7 Emulsifying power vs. $\mathrm{R}$ plots of $\mathrm{D}$-series oligosoaps.

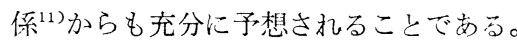

他方, $\mathrm{D}$ 系列の $\mathrm{C}_{2}$ 及び $\mathrm{C}_{4}$ 誘導体に乳化力の大きい ものがある。また，Fig.-7 は $\mathrm{C}_{10} \mathrm{D}$ 及び $\mathrm{C}_{12} \mathrm{D}$ の乳化 力対 $\mathrm{R}$ プロットである。 $\mathrm{R} \doteqdot 0.96$ の㭙の乳化力を最小 として，Rが大きくなっても小さくなっても乳化力が増 大している。Fig.-6 と対比して見る上, 乳化力の最小 值付近の Rで可溶化力は一定值に到達している。すなわ ち， $\mathrm{R} \leqq 1.0$ の領域で， $\mathrm{R}$ を増すとともに可溶化力が増 大するが，一方乳化力が低下している。M及びD系列は ともに可溶化力及び乳化力の大きさが雨立しないのであ る。なお，M系列の乳化力は小さく，かつばらついてい てRとの相関を見いだすことができなかった。

\section{5 表面張力低下能及び漫透力}

Table-3 に測定結果を示した。D系列の場合，側鎖 アルキル基鎖長を增すとともに表面張力低下能が急速に 増大し, 硫酸ドデシルナトリウム (SDS) のそれをしの ぐものがある。また，同じアルキル基鎖長ではけん化度 が小さいものほど表河張力が低下する。そして, 表面 張力低下能が大きい溶液の中に木綿及びフェルトに対し て浸透力を示すものがある。一印核浸透力試験開始後 $500 \mathrm{~s}$ 以内䚶試験布が沈降しない場合のデータである。 0.1 または 0.05 base $\mathrm{mol} / \mathrm{l}$ の濃度において $500 \mathrm{~s}$ 以内 に沈降した三つの試料法，いずれも $0.01 \mathrm{base} \mathrm{mol} / l$ の 溶液に扮いては表面張力が小さいにもかかわらず沈降し ない。すなわち, 試験布一水界面にすばやく吸着するの にはある限度以上の濃度 (分子数) が必要なことを示し ている。

$\mathrm{M}$ 系列の表面張力低下能は $\mathrm{D}$ 系列よりもはるかに小さ く，またすべて浸透力を示さない。これは，M系列の方 が高分子量（繰り返し単位数が大きい）のためであろう。 さて, ここで, $\mathrm{D}$ 系列と異なり，M系列の表面張力值は 
Table-3 Surface tension and wetting power of aqueous solutions of oligosoaps at $30^{\circ} \mathrm{C}$.

\begin{tabular}{|c|c|c|c|c|c|c|c|}
\hline \multirow{2}{*}{$\begin{array}{l}\text { D-series } \\
\text { derivatives }\end{array}$} & \multirow{2}{*}{$\begin{array}{c}c \\
(\text { base } \mathrm{mol} / l \text { ) }\end{array}$} & \multirow{2}{*}{$\begin{array}{l}\text { Surface } \\
\text { tension } \\
(\text { dyn } / \mathrm{cm})\end{array}$} & \multicolumn{2}{|c|}{ Wetting power $(\mathrm{s})$} & \multirow{2}{*}{$\begin{array}{c}\text { M-series } \\
\text { derivatives }\end{array}$} & \multirow{2}{*}{$\begin{array}{c}c \\
\text { (base } \mathrm{mol} / l \text { ) }\end{array}$} & \multirow{2}{*}{$\begin{array}{l}\text { Surface } \\
\text { tension } \\
(\text { dyn } / \mathrm{cm})\end{array}$} \\
\hline & & & Cotton & Felt & & & \\
\hline $\mathrm{C}_{2} \mathrm{D}-\mathrm{K} 89$ & 0.1000 & 50.3 & 一 & - & $\mathrm{C}_{2} \mathrm{M}-\mathrm{K} 81$ & 0.1000 & 48.1 \\
\hline$-\mathrm{K} 38$ & 0.1000 & 42.5 & - & - & & 0.0100 & 62.6 \\
\hline \multirow[t]{2}{*}{$-\mathrm{Na} 90$} & 0.1000 & 43.9 & - & - & $-\mathrm{K} 45$ & 0.1000 & 53.2 \\
\hline & 0.0100 & 52.2 & 一 & 一 & $-\mathrm{Na} 83$ & 0.1000 & 44.1 \\
\hline \multirow[t]{2}{*}{$-\mathrm{Na} 36$} & 0.1000 & 42.3 & - & - & & 0.0100 & 64.6 \\
\hline & 0.0100 & 46.6 & - & - & $-\mathrm{Na} 48$ & 0.1000 & 61.5 \\
\hline $\mathrm{C}_{4} \mathrm{D}-\mathrm{K} 94$ & 0.1000 & 39.2 & - & - & $\mathrm{C}_{4} \mathrm{M}-\mathrm{K} 82$ & 0.1000 & 49.0 \\
\hline \multirow[t]{2}{*}{$-\mathrm{Na} 100$} & 0.1000 & 41.1 & - & - & & 0.0100 & 57.6 \\
\hline & 0.0100 & 47.7 & - & - & $-\mathrm{K} 45$ & 0.1000 & 51.6 \\
\hline \multirow[t]{2}{*}{$-\mathrm{Na} 45$} & 0.1000 & 38.1 & 358.1 & 175.0 & $-\mathrm{Na} 80$ & 0.1000 & 56.0 \\
\hline & 0.0100 & 40.8 & - & - & $-\mathrm{Na} 45$ & 0.1000 & 50.5 \\
\hline \multirow[t]{2}{*}{$\mathrm{C}_{10} \mathrm{D}-\mathrm{K} 97$} & 0.1000 & 42.4 & 一 & - & & 0.0100 & 50.9 \\
\hline & 0.0100 & 51.2 & - & 一 & $\mathrm{C}_{10} \mathrm{M}-\mathrm{K} 67$ & 0.1000 & 47.6 \\
\hline \multirow[t]{2}{*}{$-\mathrm{Na} 60$} & 0.0500 & 38.2 & - & - & $-\mathrm{K} 41$ & 0.1000 & 52.5 \\
\hline & 0.0100 & 42.8 & - & - & & 0.0100 & 59.4 \\
\hline $\mathrm{C}_{12} \mathrm{D}-\mathrm{K} 100$ & 0.0100 & 45.8 & - & - & $-\mathrm{Na} 90$ & 0.1000 & 44.6 \\
\hline \multirow[t]{2}{*}{$-\mathrm{K} 39$} & 0.0500 & 37.1 & 306.8 & 330.8 & & 0.0100 & 50.2 \\
\hline & 0.0100 & 39.5 & - & - & $\mathrm{C}_{12} \mathrm{M}-\mathrm{Na} 83$ & 0.0500 & 55.0 \\
\hline \multirow[t]{2}{*}{$-\mathrm{Na} 55$} & 0.0500 & 35.6 & 284.3 & 177.8 & & 0.0100 & 56.6 \\
\hline & 0.0100 & 35.9 & - & - & $-\mathrm{Na} 47$ & 0.1000 & 60.1 \\
\hline S D S & 0.1000 & 39.2 & 7.0 & 28.9 & & 0.0100 & 60.3 \\
\hline \multirow[t]{2}{*}{$(\mathrm{mol} / l)$} & 0.0347 & 39.1 & 8.6 & 52.3 & $\mathrm{C}_{16} \mathrm{MA}-\mathrm{Na} 80$ & 0.0500 & 67.3 \\
\hline & 0.0035 & 41.0 & - & 303.2 & $\mathrm{C}_{16} \mathrm{MB}-\mathrm{K} 69$ & 0.0500 & 68.1 \\
\hline \multirow{5}{*}{$\begin{array}{l}\text { Aerosol OT } \\
(\mathrm{mol} / \mathrm{l})\end{array}$} & 0.0242 & 29.4 & 1.2 & 0.8 & & 0.0100 & 68.3 \\
\hline & 0.0024 & 30.6 & 4.6 & 4.2 & $-\mathrm{Na} 76$ & 0.0500 & 67.7 \\
\hline & & & & & & 0.0100 & 68.4 \\
\hline & & & & & $\mathrm{C}_{16} \mathrm{MC}-\mathrm{K} 82$ & 0.0500 & 62.5 \\
\hline & & & & & & 0.0100 & 65.7 \\
\hline
\end{tabular}

The cloths did not sink for less than $500 \mathrm{~s}$ in the solutions of $\mathrm{M}$-series derivatives and “- mark solutions of D-series ones.

Table-4 Dispersing power of aqueous solutions of oligosoaps at $30^{\circ} \mathrm{C}$.

\begin{tabular}{|c|c|c|c|c|c|c|c|c|}
\hline \multirow[b]{3}{*}{ Concn. $(\%)$} & \multicolumn{8}{|c|}{ Dispersing rate $(\%)$} \\
\hline & \multicolumn{4}{|c|}{ Carbon black } & \multicolumn{4}{|c|}{$\begin{array}{c}\text { Manganese } \\
\text { dioxide }\end{array}$} \\
\hline & 0.01 & 0.1 & 0.5 & 1.0 & 0.01 & 0.1 & 0.5 & 1.0 \\
\hline $\mathrm{C}_{2} \mathrm{M}-\mathrm{K} 81$ & 20 & 19 & 24 & 22 & 4 & 0 & 2 & 0 \\
\hline $\mathrm{C}_{12} \mathrm{M}-\mathrm{K} 80$ & 26 & 30 & 一 & - & 2 & 6 & - & - \\
\hline $\mathrm{C}_{16} \mathrm{MA}-\mathrm{K} 60$ & 25 & 28 & 46 & 43 & 7 & 2 & 1 & 0 \\
\hline $\mathrm{C}_{16} \mathrm{MB}-\mathrm{K} 69$ & 13 & 27 & 26 & 32 & 1 & 2 & 3 & 2 \\
\hline $\mathrm{C}_{16} \mathrm{MC}-\mathrm{K} 82$ & 11 & 27 & 30 & 40 & 1 & 2 & 3 & 2 \\
\hline SDS & - & 5 & 9 & - & 一 & 1 & 1 & 一 \\
\hline Aerosol OT & - & 5 & 56 & - & 一 & 0 & 5 & - \\
\hline Demol N* & 22 & 80 & 82 & 82 & 4 & 3 & 11 & 10 \\
\hline
\end{tabular}

* Addition-condensation product of sodium naphtha $=$ lenesulfonate and formalin.

$\mathrm{C}_{2}$ から側鎖アルキル基鎖長を伸ばすとともに一たん低 下した後, 再び上昇を始め $\mathrm{C}_{16}$ 誘導体では $68 \mathrm{dyn} / \mathrm{cm}$ 前 後にまで到達するこ上は注目に值する。モノソープにお
ける通念から類推すれば，D系列のように側鎖アルキル 基鎖長を増すとともに表面張力が低下するはずである。 Rosen $^{9)}$ は，水溶液中におけるアルキルベンゼンスルホ ン酸塩のアルキル鎖長と表面張力低下能との関係を調 べ， $\mathrm{C}_{14}$ まではアルキル鎖長を増すとともに表面張力が 低下するが， $\mathrm{C}_{16}$ になるとかえって表面張力が増大する ことを見いだした。この理由として $\mathrm{C}_{16}$ ベンゼンスルホ ン酸塩の強いミセル化傾向によって単分子の表面吸着が 妨げられること，すなわち，ミセル化と表面吸着とが競 合することを考えた。

$\mathrm{M}$ 系列における側鎖の長い誘導体の表面張力上昇も同 様の作用機構が考えられる。すなわち, 水溶液中におけ る $\mathrm{C}_{16}$ 誘導体の強い分子間会合傾向についてはすでに 報告済み(3),4゙あるが，この傾向によって本来かさ高く て身動きしにくいオリゴソープ及びポリソープ分子の表 面吸着を有効に妨害するため水に近い表面張力值 (68 dyn/cm) をもたらすのである。

\section{$3 \cdot 6$ 分散力}


Table-5 Flocculating power for dispersed caolin of aqueous solutions of olygosoaps at $30^{\circ} \mathrm{C}$.

\begin{tabular}{|c|c|c|c|c|c|}
\hline & \multirow{2}{*}{$\begin{array}{c}\text { Sedimentation } \\
\text { rate } \\
(\mathrm{ml} / \mathrm{min})\end{array}$} & \multicolumn{2}{|c|}{$\begin{array}{c}\text { Transparency of } \\
\text { upper layer }\end{array}$} & \multirow{2}{*}{$\begin{array}{l}\text { Final } \\
\text { sedimentation } \\
\text { volume } f(\mathrm{ml})\end{array}$} & \multirow{2}{*}{$\begin{array}{l}\text { Filtration rate } \\
(\mathrm{ml} / \mathrm{min})\end{array}$} \\
\hline & & $\begin{array}{c}\text { Transmittance } \\
(\%)\end{array}$ & Eye obsd. ${ }^{* 2}$ & & \\
\hline $\mathrm{C}_{2} \mathrm{M}-\mathrm{K} 81$ & 0 & 0 & $\times$ & 2.0 & 2.0 \\
\hline $\mathrm{C}_{12} \mathrm{M}-\mathrm{K} 80$ & 6.0 & 61 & $\Delta$ & 2.9 & 4.8 \\
\hline $\mathrm{C}_{16} \mathrm{MA}-\mathrm{K} 60$ & 3.4 & 35 & $\Delta$ & 2.8 & 4.0 \\
\hline $\mathrm{C}_{16} \mathrm{MB}-\mathrm{K} 69$ & 6.0 & 0 & $\times$ & 3.0 & 4.8 \\
\hline $\mathrm{C}_{16} \mathrm{MC}-\mathrm{K} 82$ & 5.0 & 26 & $x$ & 3.0 & 4.8 \\
\hline S D S & 3.0 & 37 & $\Delta$ & 3.0 & 4.0 \\
\hline Aerosol OT & 4.0 & 39 & $\triangle$ & 3.1 & 4.0 \\
\hline Demol N & 3.0 & 4 & $x$ & 2.8 & 4.0 \\
\hline Polyacrylamide & 8.0 & 82 & 0 & 3.8 & 5.0 \\
\hline $\mathrm{AH}-150 \mathrm{P} * 1$ & 32.0 & 95 & 0 & 4.8 & 12.0 \\
\hline $\mathrm{N}-50 \mathrm{P} * 1$ & 35.0 & 97 & 0 & 4.5 & 11.0 \\
\hline $\mathrm{C}-450 \quad * 1$ & 12.0 & 85 & 0 & 3.5 & 4.8 \\
\hline Water & 2.0 & 24 & $x$ & 2.9 & 4.4 \\
\hline
\end{tabular}

$*_{1}$ Flocculating agents (Sanyo Kasei Co.)

*2 $\bigcirc$ : good clarity, $\triangle$ : somewhat turbid, $\times:$ turbid

無極性分散質であるカーボンブラックと極性分散質で ある二酸化マンガンとを用いて，M系列の $\mathrm{K}$ 塩の側鎖ア ルキル基鎖長及び繰り返し単位数を変化させた時, 分散 力が変化する様子を Table-4 に示した。高分子電解質 である $\mathrm{C}_{2} \mathrm{M}-\mathrm{K} 81$ のカーボンブラックに対する分散力は 長鎖アルキル基を持つものに比べて小さいが，二酸化マ ンガンに対する分散力は同程度で差異が明らかでない。 $\mathrm{C}_{16} \mathrm{M}$ における繰り返し単位数 (分子量) の相違が分散 カに与える効果は, 三つの中で繰り返し単位数が最小の $\mathrm{C}_{16} \mathrm{MA}-\mathrm{K} 60$ のカーボンブラック分散力が最大のもので ある。二酸化マンガンに対しては同等の分散力を有して いる。文献 ${ }^{22)}$ によると, SDS の両分散質に対する分散 カは，アニオンモノソープ中では比較的上位にある。従 って，M系列の分散力はアニオンモノソープと比べれば よい部類に入る。しかし， $\mathrm{cmc}$ 以上のエーロゾル OT よ りも劣り, また, 市販の分散剤であるデモールNよりは はるかに劣っている。

\section{7 カオリン㥿濁液に対する疑集力}

Table-5 に結果を示した。M系列において側鎖アル キル基が長いもの及び繰り返し単位数が大きいものほど 各項目の值がよくなっている。繰り返し単位数が大きい ものの方が，小さいものよりも凝集力が大きいことは, すでによく知られている。また，側鎖アルキル基が長い ものも，水とほぼ同様の効果であって，疎水領域の形成 がカオリンの凝集効果に関与しないことがわかった。す なわち, 凝集剤の作用を, 静電的な作用（カオリン粒子 表面の負電荷に対する効果）とポリアクリルアミドのよ らに水素結合だけによる吸着の効果の二つに分けて考え ることができよう。さらに，カオリンの板状結晶の凝集
構造に依存して $v_{f}$ が変化するが，面と面よりも端と端 または端と面の結合が多いかさばった構造の方が疑集効 果が優れていること年加考えると， $\mathrm{C}_{2} \mathrm{M}-\mathrm{K} 81$ はむし ろカオリンに対して分散力を有している。これは, 水素 結合により $\mathrm{C}_{2} \mathrm{M}-\mathrm{K} 81$ がカオリンに吸着して自身の負 電荷によりカオリン粒子上の負電荷を増大させ，分散性 を増す傾向を示すのであろら。そして，側鎖アルキル基 が長いとカオリンに吸着しにくいことになる。

(昭和 52 年 7 月 27 日受理)

\section{文 献}

1）石上 裕, 鈴木 洋, 楢崎英男, 油化学, 26. 774 (1977)

2) S.H. Yalkowski, G. Zogrefi, J. Pharm. Sci., 61, 793 (1972)

3）石上 裕, 楢崎英男, 油化学, 21, 324 (1972)

4) 石上 裕, 油化学, 25, 90 (1976)

5）桜井雅男, 小松 剛, 中川鶴太郎, 日化, 1976, 191

6) N. Ise, T. Okubo, J. Am. Chem. Soc., 90, 4527 (1968)

7) B.E. Conway, J.E. Desnoyers, A.C. Smith, Phil. Trans. Roy. Soc., 256, 389 (1964)

8) J. Millero, "Water and Aqueous Solutions" (Ed. R.A. Horne), Wiley, New York (1972), New York

9) M.J. Rosen, J. Am. Oil Chem. Soc., 49, 293 (1972)

10) P.L. Dubin, U.P. Strauss, J. Phys. Chem., 74, 2842 (1970)

11）高橋, 難波, 小池，小林編，“界面活性棛ハンドブック” 工学図書 東京 (1968), p. 183,

12) A.M. Mankowich, Ind. Eng. Chem., 44, 1151 (1952)

13）鈴木静夫, 表面, 9, 557 (1971)

14）坂口嘉平, 長瀬邦彦, 工化, 69, 1192 (1966) 